\title{
Deities and Their Symbolic Representation in Traditional Igbo Community: A Case Study if Alaogbaga Deity in Chokoneze Mbaise
}

\section{| Madukasi Francis Chuks ${ }^{1, *}$ | Ahamba Lilian Nneka² |}

${ }^{1,2}$ Chukwuemeka Odumegwu

Ojukwu University,

Department of Religion \&

Society. Igbariam Campus, Anambra State, Nigeria.

*frankmakson@gmail.com

\begin{abstract}
Alaogbaga was/is an arbitrator of justice and morality. This deity was revered and respected by the people unlike today where the deity is relegated to the background. This research work discusses deities and their symbolic representation in an Igbo community focusing on Alaogbaga deity in Chokoneze Ezinihitte Mbaise local government area. The data collected were analyzed using the area cultural approach. In the course of the study, the researcher found out that Christianity, modernization and globalization are the agents that contributed to the weakening of the cultural heritage of Chokoneze people and the destabilization liturgical worship of Alaogbaga. The assimilation of these agents brought about negligence and abuse of the deity by different cadre. The effect of this negligence led to the weakening of the cultural heritage and in consequence the weakening of the moral practices associated with the traditional norms. This research will be beneficial to different cadre and will help enlighten and awaken the minds of the people. The researcher recommends that the people should go back to their root and reconcile with the positive traditions and moral values of their forefathers to help reduce the increasing rate of immorality. The Christian community together with the traditionalist should try to incorporate the teaching of the positive traditions of the community in their different organizations. Cultural studies should be included in the educational curriculum at all levels. This will help awaken the interest of the youths towards their cultural heritage and in turn give them a sense of identity.

KEYWORDS

Ancestor; cult; deity; sacred.
\end{abstract}

\section{INTRODUCTION}

The belief in the cult of deities is a phenomenon that is generally acknowledged in Africa. The belief in deities is evident in the myths associated with the existence of mermaid spirits, spirits of the dead, and other spirit forces unknown to man which are predominant among African communities. These beliefs have great influence in the lives of the people which are evident in their worldview, values and attitudinal orientations. Alaogbaga deity is believed to be a powerful spirit force highly reverenced and respected by Chokoneze people. Chokoneze is a town in Ezinihitte Mbaise made up of two autonomous communities; Umuchoko and Umueze. Umuchoko is made of small kindred's like Umuola, Emedike, Umuajala (where the shrine of Ajala deity is located, although it is no longer functional) etc. In Umueze we have; Umuorieaku or Umuke (it is the elders of this kindred that strived to get Alaogbaga into Chokoneze and the own the land where the shrine of Alaogbaga was first erected in the boundary between Ndiuhu and Umunama), Ndiuhu (the former location of 
Alaogbaga shrine). Ndiuhu share a boundary with Umunama, a kindred in Oboama in Aboh Mbaise local government. Umuowuru (where the shrine of Alaogbaga is presently located after Umuke people relocated to from Ndiuhu to another side of the town).

The position of the shrine is behind the Chokoneze market square, formerly known as Orienta but now called Ekeoha. Chokoneze is strategically located at the heart of Ezinihitte Mbaise that the presence of the shrine of Alaogbaga deity close to the market square gives a sort of identity and security to the people. From the beginning, the life, culture and existence of the ancients of Chokoneze were fabricated around the deity, this is because the presence of the deity helped to shape the lifestyle and morals of the people. It is an arbitrator of justice and morality. It is known as the goddess of justice. The court of the deity holds every Nkwo-ala and Afor market day. The Nkwo-ala court holds at the shrine mainly for serious cases like murder, land dispute, incest etc while the Afor court holds at the hall in the chief priest's compound for settlement of loans and quarrels. This court is mainly held for women. The name Alaogbaga was coined from two words; Ala-earth deity (the original name of the deity) and Ogbaga (a particular yam cultivated by Umueze people which somewhat became their identity.

When the deity Ala was brought into being, Umueze people decided to incorporate their identity (Ogbaga people), hence, the name Alaogbaga (Ala deity of Ogbaga people). Its sacred animal is the tortoise. Alaogbaga also have the native cows which are sacred to her. These cows are brought together with $o h u$ dedicated to the shrine by their masters as servants to the deity. They are never sacrificed unless the deity demands so. Calamity befalls anyone who harms the totem accidently and did not go to appease Alaogbaga. The presence of the deity pricked the conscience of the people. It is believed that the deity protects, settles disputes justly, enforces orderliness in the community and prospers their businesses. There was a case were Alaogbaga killed a man for greedily taking another man's land and refusing to relinquish it. She separated fight among secondary school students. Its totemic animal went round the community making sure things were in order and waking families who were laying asleep outside during ungodly hours. Immoral acts like; adultery, incest, fornication, fighting, stealing and murder where not as rampant as it is today.. Cases were brought before her and instant settlements were achieved. These qualities are still active and effective like before. From old till now, every average Chokoneze indigene will immediately relinquish any belonging of another which he greedily took at the mention of the court of Alaogbaga. In Chokoneze, the worshippers of Alaogbaga deity attribute socio-religious function to the deity; control of crimes, settling of disputes, protection of norms, cultures and traditions, promotion of human rights, promotion of love and peace, security etc. It serves justice and enhances morality in the community. Deities are believed to be custodians and guardian angels on earth, for this, it is necessary for the living to maintain good relationships with them. This good relationship is only achieved through reverence and worship. There are stories about deities that are terror to the members of their community. But Alaogbaga deity is not one of such deities neither are her servants. She always protects her people and settles disputes justly.

The fear of Alaogbaga's undiluted justice is no longer an agent to checkmate morality as it used to be. It has been neglected by the people; the shrine is no longer properly cared for. It is no longer the concern of the whole community but a few who still value their tradition. The attendance/patronage to the shrine has drastically reduced. It can be said that people from the neighboring communities are the most patrons of the shrine. The celebration of its yam festival which used to be elaborate, unique with many in attendance is no longer celebrated like before, now it is a matter of two who it may concern. The new yam festival is the only festival celebrated in the name of the deity. It takes place every $15^{\text {th }}$ of august 
before the community can celebrate. It is a means of acknowledging and appreciating the deity for the good works it is doing in the community. The deity has been abused in different degrees, firstly by the Christians who try to violate its traditions and destroys its shrine. According to E. Agbakwuruibe (personal communication $30^{\text {th }}$ march 2018) in 1988, Emmanuel Njoku a deeper life pastor went to the shrine claiming to have the power to destroy the deity and burn down the shrine. He was put to sleep in the shrine for three days and the people believe that that was the handiwork of the deity. Another pastor from the Anglican Church in Chokoneze supported an osu family and buried one of their own without performing the necessary rites at the shrine before his burial according to the custom. It was said that two days after the burial he died in his sitting room after narrating to his wife of his ordeal with a mysterious woman who he mentioned as Alaogbaga. It has been abused by one of the chief priest the chief priests, wanted to use her against her will and he ended up violating her tradition and it is believed that this caused his untimely death. During the time of our forefathers, the chief priest of Alaogbaga was respected like the deity. But today they are insulted and even fought. The cultures and traditions of our forefathers are relegated to the background while the youths go about propagating the alien culture which in most ways in contrary to the moral values handed down by our ancestors. This all came with the advent Christianity and modernization.

Despite changes brought about by Christianity and modernization, Alaogbaga still maintains its influence on some of its community members and the neighboring towns. Against this background, there is need for a phenomenological study of Alaogbaga deity and its socio-religious influence, relevance and function on the people of Chokoneze from the beginning to the present in order to filter out the positive influences to foster good relationship between the people's cultural heritage and modernity.

This study therefore is an attempt to bring to light the benefits and functions of Alaogbaga deity and to renew the peoples mind towards their culture and traditions. This will help to reduce the immoral acts in the society brought by Christianity and modernization.

\section{RESEARCH METHOD}

This is the systematic study of methods that are, can be or have been applied within a discipline. In this research work the instrument for data collection for this study consisted of both primary and secondary sources. The primary sources consisted of interviews, observations and oral tradition, while the secondary sources consisted of documented materials both published and unpublished work of related works on deities and the history and culture of Chokoneze people. The data collected were analyzed using the area-culture approach of interpretation. This was most suitable because of the culture bound nature of the study. This helped the researcher to maintain originality.

\section{Concept of Deities}

For many decades, the concept of deities in Igbo traditional religious thought has been a controversy. According to Metuh (1981) these controversies includes lack of written documents, lack of indebt study of traditional religion leading to hasty conclusion, prejudice by western scholars who misconceived traditional religious concepts with Christianity and language barriers. Mbiti (1970) agrees by saying that most of the scholars who came to study the indigenous religions were armchair scholars who depended on data from missionaries who themselves concentrated in one community or tribe. They used the scanty information derived from one or two localities to draw conclusion about the ontology of deities. According to Idowu (1962) the belief in the existence of deities is fundamental in an Igbo society. Brown (1975) says deities are spirit beings that reveal themselves in many different 
ways and human beings have always felt its presence and responded in worship. Mbiti (1975) contributes thus; these revelations have brought about a relationship between mankind and the deities leading to what we now call religion. The greatness of deities is also portrayed in African traditional religion by Mbiti (1975) when he explained that, "though the knowledge of deities is not documented in any sacred book, yet it is expressed by proverbs, short statements, songs, prayer, names, myths, stories and religious ceremonies" (p. 60).

Mbiti (1975) asserts that Africans express their concept of deities in the attributes accorded to them. They personify nature's gifs like forest, groves, trees etc. and dedicate them as representatives of the presence of deities. According to Mbiti (1970) in traditional religion, deities are not considered to be living beings, but in order to express certain concepts, they employ anthropomorphic language and images about it as an aid to their conceptualization of it who they have not seen and about whom they confess to know little or nothing. According to (Njoku (2002) divinities have been grouped into two major groups namely: the principal divinities and minor divinities. Principal divinities are regarded as part of the original order of things. Njoku (2002) sees these as being "co-eval with the coming into being of the cosmos". They include such divinities as Amadioha - thunder divinities, Ani or Ala - earth divinity. Explaining the African concept of deities, Mbiti (1975), argues that divinities were created by the Supreme Being. He explains that divinities "have been created by God in the ontological category of the spirits. They are associated with Him, and often stand for His activities or manifestation either as personifications or as the spiritual beings in charge of these major objects or phenomena of nature" (p.75-76). Idowu (1962) agrees that divinities were not created but were brought out into being.

\section{The Symbol and Structure of Alaogbaga Deity}

According to Essien (1978) "phenomenology is a careful analytic description. It lets one to see that which shows itself (namely phenomenon), by removing as far as possible concealments, distractions and whatever else that might prevent us from seeing the phenomenon as it actually gives itself' (p. 12). Ejizu (1986) demonstrated this in his study of ofo ritual symbol in Igbo traditional religion. He said, "The method is best suited for unraveling the structure of symbol as it allows the datum to speak for itself, so to speak, rather than be forced into any pre-conceived scheme. It is equally helpful in revealing how the various aspects of a particular religion hang together and permeates the various levels of the social life" (p.21).

Alaogbaga deity therefore has a structure and it is very possible to study it in its structure as it presents itself to a researcher. It is possible to have a phenomenological study of this structure without first having preconceived intention. A careful analytic study of Alaogbaga deity as it relates to Chokoneze people involves the clarification of some relevant issues and these were achieved through oral tradition and personal communication. According to $\mathrm{M}$. Ahamba (personal communication $27^{\text {th }}$ March 2018), Alaogbaga deity is a just deity highly reverenced, respected and feared not because it is dreadful or a terror but because of its impartial nature. It is because of this good nature that the shrine is highly patronized by the people and their neighboring villages and far. It is believed by the people that Alaogbaga has control over certain natural occurrences. N. Izimah (personal communication, $28^{\text {th }}$ March, 2018) speaking on this said that, Alaogbaga is a mysterious deity. It takes different forms to accomplish its mission; as an old man, young or small boy, bee, tortoise, and millipede, snake, and soldier ants and small moulded molds. He further said that the deity does not strike evil doers without a fair warning and if an evil doer willingly confesses and asks for forgiveness before the shrine, he will be pardoned but no third chance of fair judgment will be issued if he persists in his evil ways. It does not kill nor harm an innocent 
man. During the time of our ancestors, if a man is killed by Alaogbaga, he is buried in the deity's forest after all necessary sacrifices have been performed but as time passed, the people pleaded for the body of their own to be buried in their homestead and this request was granted but the necessary sacrifices must be performed before the burial and it is forbidden for his body to be taken to the mortuary or embalmed at home until the necessary sacrifices demanded is completed. There was a case where an Anglican priest was killed by the deity for defiling the custom. The priest buried an osu without the necessary rites been performed. According to the custom, an osu belong to the deity and at death certain rites must be performed before he/she can be buried either by the church or traditionalists. Few days after the burial, the priest met his sudden death at his sitting room while preparing to eat dinner. Sacrificial rites were performed before his remains were led to rest. And the living members of the $o s u$ household still performed those rites which they felt wasn't necessary. According to D. Anyanwu (personal communication, 28 $8^{\text {th }}$ March, 2018) before a man is killed by Alaogbaga, certain unusual events unfolds (ehiehi). Such as; bunch of bees circling the person's house, soldier ants, millipedes etc. He in return is expected to go to the shrine to find out what these visits signifies and what to do about it. If these warnings were not heeded, death comes either with swollen body, weeping cough, road accident with an old bicycle man or the tongue been dragged out of the persons mouth by an unknown force etc. There is obvious consciousness of the deity in the community. The worshippers of Alaogbaga deity believe that the deity helps to preserve their community and their conducts do not in any way contradict their belief in the Supreme Being but instead are complementary to it. Alaogbaga deity according to M. Njoku (personal communication $29^{\text {th }}$ March, 2018) does not work alone. There are other deities that are under the command of Alaogbaga deity and they stand as trees around the shrine and are used by Alaogbaga to achieve different missions. They receive their fair share of sacrifices from the chief priest of Alaogbaga. These trees are distinguished among the ordinary trees in the shrine by the palm frond tied around their waist. This symbolizes the sacredness of the trees. They stand in different positions around the shrine of Alaogbaga. Ajala and Agwunsi stand at the vertical entrance of the shrine. Ogwugwu and Imo mmiri stand at the horizontal entrance of the shrine. Amadioha and $O$ fo na ogu stand by the sides of the shrine. Because the people believe, respect and feel that the deity controls their life, they look up to and consequently, offer sacrifices and worship to it. On the origin of the deities, the people had varied opinions. D. Anyamele (personal communication $29^{\text {th }}$ March 2018) said that deities are spirit beings brought to being by God to help look after the affairs of men.

According to M. Nwamara (personal communication $29^{\text {th }}$ March 2018) deities are angels of God who were sent down to earth to domesticate among men, to control and checkmate their activities. O. Cyprus (personal communication 29 $9^{\text {th }}$ March 2018) said that deities are manmade, agents of devil used by men to accomplish their heinous evil acts. Elaborating further he said, I have nothing against Alaogbaga and its worshippers but as a Christian I believe it to be wrong for men to worship another god aside the supreme God. The people believe that by living according to the stipulated rules and regulations of the deity, one can gain salvation i.e. avoiding transgressions and abominations. According to Iroegbu (2009), the deities having descended from God, the people are of the claim that they are the first transcendental spirit beings encountered by their ancestors and used by them to mediate their cultural, economic, socio-religious and political life.

\section{The shrine of Alaogbaga Deity}

Alaogbaga liturgical worship and court is carried out at the shrine of the deity located at Umuowuru Umueze in Chokoneze Mbaise. However minor sacrifices were being performed 
at the shrine of Ajaala in Umuajala in Umuchoko in Chokoneze according to the demand of the deity. After Umuchoko separated from Umueze and formed their own autonomous community, they choose a male deity Ajala as their deity and erected a shrine for it at Umuajala. Ajala was/is one of the messenger deities of Alaogbaga also believed to be her son. Because of unpreparedness and lack of management, the shrine seized to function. The shrine still exists but no functional activities goes on there. However, the deity still stands as a tree at the shrine of Alaogbaga as a messenger spirit receiving its rewards just like the other messenger spirits. The shrine of the deity is established behind the village market square known as eke oha. It consists of a small mold cement house roofed with old zinc. The size of this hut tallies with Arinze's (2008) calculation about the size of most shrines which, generally, is not large enough to shelter more than a few people. According to the present care taker G. Onyeike (personal communication $6^{\text {th }}$ April 2018), there are no wooden carved images in her shrine. The inside of her shrine is as empty as an open ground. There is no symbolic image representing the deity which is found in her shrine except her obi ттио. This is because the deity is represented as the name implies (Ala). Unfortunately the inside of the shrine cannot be snapped for it is said to be a sacrilege against her honor. There is a small hall close to the shrine where worshippers and those who have cases in the shrine settle to wait for their turn to be administered. There is also another hall at the compound of the chief priest. It is where most cases involving women are settled. Also other unserious cases are held there and this takes place every afor market day. Behind her shrine stands her forest. Hunters are allowed to hunt in the forest. Even women and children go on snail hunting at night in the forest unless on specific days which will be publicly announced. Around the shrine are trees representing the subordinate deities used by Alaogbaga to carry out different missions. At the back of the shrine an area secluded from the other parts of the shrine with оти $n k w u$ (palm fronds) where sacrifices are performed. Nobody including the priest steps into this place wearing anything on their feet. Handsets are not allowed at the shrine. The picture of the shrine and its environment is attached below. The people have different views on the meaning of shrine and its significance in any community. M. Nwamara (personal communication $29^{\text {th }}$ March 2018) said that a shrine is one of the most important buildings needed in a community. Its presence helps to checkmate the morals of the people. It is the abode of the deity and it is also a place where sacrifices are offered to the deity to appease it. M. Ahamba (personal communication $27^{\text {th }}$ March 2018) said "A shrine in a community incites the fear of the presence of a supernatural force beyond our human power. A shrine is a sacred place where people go to seek for justice and solutions".

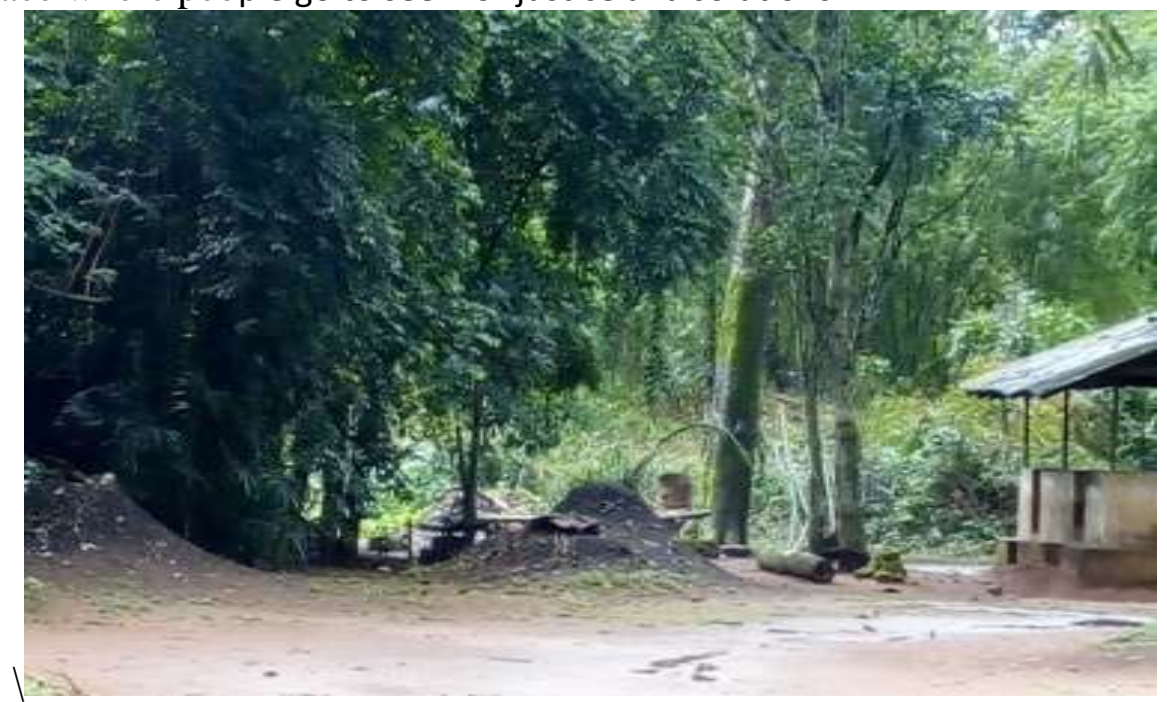

Figure 1. Picture of Alaogbaga shrine and its environment 


\section{Symbolic Functions and Importance of Alaogbaga Deity in Chokoneze}

Alaogbaga deity was said to have existed before the advent of Christianity in Chokoneze. Consequently the life, culture and existence of the aborigines of Chokoneze were woven around the deity and its worship. According to Obiechina (1978), "traditional Igbo religion was and still is inextricably bound up with Igbo culture" (p.208). Before the advent of Christianity and modernization, there was strong connection between their daily activities and the worship of the deity. The deity controlled their lives, culture, moral values, customs and traditions. There was serious Alaogbaga consciousness. The Alaogbaga deity is bound with Chokoneze "omenala" and they live their lives according to what omenala dictates so as to ensure order and decorum in the society. The roles of the deity in Chokoneeze community will be discussed below.

\section{Political Functions}

Alaogbaga shrine is used as a court to ensure justice; equity and sincerity in communal relations. Worshippers report disputes at the shrine for settlement. The report is usually made with some items involving a certain amount of money and other native items depending on your complaint. This is traditionally referred to as "itu omu". At the receipt of this report, an emissary from the shrine will be sent to the accused inviting him to the shrine for a defense on a given date which must be on nkwo or afor market day corresponding to the day of the worship of the deity. To answer the invitation, the accused will come with either schnapps or palm wine and kola to the shrine. At the commencement of discussion the chief priest will bring the ofo and make invocations calling upon the spirit of the deity to come and witness. The accused and complainant are to off their foot wears and stand in front of the shrine and swear by the ofo declaring that all they will say before the shrine is nothing but the truth. It is also a means to checkmate the activities of the traditional ruler and the chiefs. During the crowning of a king the priest of the deity uses the ofo on the crowned king urging him to be true to his words and be a good ruler or face the wrath of the deity. It is used enormously to enforce compliance to established traditional rules and norms. This is done by the chief priest who uses the ofo with the authority of the deity to pray and declare the practices permissible and abominable.

\section{Social Functions}

It is used for oat taking to determine the truth especially in matters of controversy. During such cases, the ofo is brought out and the parties are asked to remove their foot wear and stand before the shrine and then incantations by priest followed up with prayers. The priest brings fought the Igbo kola nut, prays on it and breaks it. The parties are then offered one of the lobes of the kola and warned to speak nothing but the truth for there will be grave consequence if an atom of falsehood is dictated by the deity. It is the cheapest and last resort for the under privileged in the community.

There is no bias and no bribery associated with matters involving the deity. The rich and the poor are treated equal before the deity. Even the priest receives his punishment from the deity when he derails. There is no distinction between the free born and $o s u$. According to G. Onyeike (personal communication, $6^{\text {th }}$ March, 2018) the second care taker of the deity was an $o s u$ and his family still serve at the shrine till date. They are equal in every matter of the society except kingship and marriage basically from Umueze clan. It is used to preserve traditional festivals. The priest in connection with the traditional ruler determines the days and mode of celebration of traditional festivals. In a festival like the new yam festival nobody is allowed to celebrate the new yam until it is celebrated in the shrine of the deity on $n k w o$ 
market day before public celebration. It encourages communal living and social interaction especially during the numerous festival celebrations.

\section{Religious Functions}

It incites in the people the consciousness of a powerful being and mans dependence on that being. It stands as an agent for checkmating people's behavior and to correct and control their excesses. This helps to reduce the incidence of murder, stealing and other vices in the community. During worship they pray for success and good health for themselves, their present families and future families believing that it will come to past. According to E. Onuzor (personal communication, $7^{\text {th }}$ April 2018), the deity saves its citizens from harm when called upon. For example, if a woman is being attacked on her way back from the market, she can appear in form of a man to rescue the woman, she can appear in form of a motorcycle rider to take a pregnant woman who has no help to the hospital or to help a stranded person. She separates fights among siblings and school students. It does not accommodate evil charms in the community. She doesn't discriminate against osu for they are free to serve and worship in her shrine. It neutralizes any charm brought into the land by either a foreigner or indigene and punishes such offender accordingly. Although there are people who managed to bring in evil charms into the community, they meet their doom in the long run. She encourages community consciousness and oneness.

\section{The Influence of Christianity; Modernization and Globalization in the Worship of Alaogbaga Deity.}

According to Onwu (2002) the coming of Christianity into Igbo land in 1842 was rightly perceived as a civilizing mission. It meant the introduction into the relatively stable Igbo traditional religious framework of an alternative view of the world, a rival cosmology and a different way of understanding the place of Igbo people in creation. This encounter marked the beginning of the restoration of the broken link and what has been the development implication of modernity. The encounter between the Igbo indigenous religion and western culture was put clearly by Achebe (1958) when he said that the white man has put a knife on the things that held us together and we have fallen apart. Achebe asserts here that the Igbo culture and sense of solidarity and communalism were polluted by new cultural forces which they were not prepared to take seriously or engage with. With the introduction of Christianity, western culture advanced unabated. Westernization resulted in the destruction of Igbo culture and imposition of alien ways of life. This exposure to new forms of life and the possibilities it offered brought drastic changes to people's world views. Ekpunobi and Ezeudu (2011) noted that "some aspects of the traditional values and morality have been influenced by the processes of modernity that are passing through the African societies.... Some values and morality are wearing new frames in order to grapple with the increasing socio-religious problems of the contemporary society. Therefore, it becomes necessary to ask if the Igbo culture did not have the flexibility to go through the huge cultural changes and influence and still retain some of its core feature. (P.99-144).

Christianity came with Western education, improved knowledge, science and technology thereby, breaking a number of traditional barriers and widening people's horizon and potentialities. So, based on this fact, many traditional religious worshippers have abandoned their age-long tradition and belief to embrace Christianity. More so, with the rapid conversion to Christianity and embrace to modernization the worship of Alaogbaga deity slowly losing its efficacy and other vital cultures like, masquerades dances are lost to modernity since the youth of this era shows very little interest to them. 
The advent of Christianity in Chokoneze meant the introduction of a Christian world view. The Chokoneze people have embraced Christianity and western culture which have displaced the traditional religion in its organized form yet the traditional religious beliefs and practices still rule the minds of many Chokoneze Christians. The average Igbo Christian would not normally participate in the public worship of deities but would resort to deities for help when difficult life situations such as illness, misfortunes, deaths, barrenness, present themselves for solutions. In this situation, culture clash is inevitable as the dominant culture strives to over throw the recessive culture. As conflict emerges, new modes of behavior and lifestyle emerge which results in new identity. There is no much respect left for the deity. The shrine have been neglected, it is no longer the concern of the whole community but a few who still value their tradition. The attendance/patronage to the shrine has drastically reduced. The celebration of its yam festival which used to be elaborate, unique with many in attendance is no longer celebrated like before, now it is a matter of two who it may concern. The deity has been abused in different degrees, firstly by the Christians who try to violate its traditions and destroys its shrine. According to E. Agbakwuruibe (personal communication $30^{\text {th }}$ march 2018) in 1988, Emmanuel Njoku a deeper life pastor went to the shrine claiming to have the power to destroy the deity and burn down the shrine. He was put to sleep in the shrine for three days and the people believe that that was the handiwork of the deity. Another pastor from the Anglican Church in Chokoneze supported an osu family and buried one of their own without performing the necessary rites at the shrine before his burial according to the custom. It was said that two days after the burial he died in his sitting room after narrating to his wife of his ordeal with a mysterious mystery woman who he mentioned as Alaogbaga. According to G. Onyeike (personal communication $6^{\text {th }}$ April 2018) in the year 1982, one of our sons Jonathan Anyanwu, came back home with the interest to build his house but unfortunately the only land for him to build is close to the shine of Alaogbaga and is a dumping ground were those killed by Alaogbaga are thrown. Christianity no doubts brought about certain positive changes and because of modernization our youths are no longer interested in the cultural values of their forefathers which shaped their lifestyles and behaviors. Immoral acts like adultery; homosexuality, murder, stealing, and incest are now openly propagated. Westernization which dislodges and destroys traditional culture and imposes western ideologies on the people is not the best. No culture should claim superiority over the other, rather the integration of both should be the best approach. The Igbo's for instance had lived with their culture long before the advent of Christianity and Westernization. This imposition of Western culture has actually led to clash of cultures and the implication is the resilience of Igbo culture.

\section{CONCLUSION}

From the above, it has been discovered that Alaogbaga deity has positive socio-economic and religious influence on the lives of the people of Chokoneze community. Positively, it helps to maintain peace and harmony among its members especially through the individual and communal oath-taking ceremony oftentimes administered by the priest of the deity during the settlement of disputes. More so, it promotes unity and solidarity ensuring a kind of symbiotic relationship among its adherents and the entire Chokoneze community. It does not encourage "Osu" caste system where some members are excommunicated and ostracized from the rest of the cult. These people can participate in any public gathering like every other member of ther community. Hence, in this way, the deity denies no members of the community their natural right of socialization and felicitation. Also, due to its nature, every member of the community enjoys equal freedom and opportunity for religious participation and officiating in the worship of Alaogbaga deity. Officiating has always been an exclusive 
reserved for the male priest from the priestly family and a caretaker can be selected from any family in Umueze. This study found out that Christianity, modernization cum globalization has reduced the worship of Alaogbaga deity. Many of its young worshippers have been converted to the new Christian faith, leaving only but few elders to their traditional faith. Young men who could perform some acrobatic dances and masquerade dances during the festival and celebrations are no more interested. Many equally have left their home land to the cities probably due to urbanization thus, deserting the village which has been the center for all festivals and other socio-religious ceremonial activities. Some are even ashamed of cultural heritage of their community. Some see them as barbaric and primitive. They have assimilated the alien culture and religion to the extent that all they have left is a fragment of their culture and identity.

\section{REFERENCES:}

Achebe, C. (1958). Things fall apart. London: Heinemann

Agbakwuruibe, E. (2018). Personal Communications.

Anyanwu, D. (2018). Personal Commuincations.

Anyamele, D. (2018). Personal Communications.

Arinze, F. A. (2008). Sacrifice in Igbo Traditional Religion. Onitsha: Saint Stephens.

Ahamba, M (2018). Personal Communications.

Brown, D. A. (1975). A guide to religion. London: Spck.

Cyprus, O (2018) Personal Communication.

Ejizu, C. I. (1986). Ofo: Igbo ritual symbol. Enugu: Fourth dimension.

Ekpunobi, E. \& Ezeudu, A. (2011). Moral Values as the Pivot for Sustainable development

Nigeria. In J. F. Oloidi (ed.), Nigerian Peoples Culture and Development. Eungu: Ebenezer.

Idowu, B. (1962). Oludumare: God in Yoruba belief. London: Longmans.

Izimah, N. (2018) Personal Communication.

Iroegbu, P. E. (2009). Igbo okija oracle and shrines, development and cultural justice.

Retrieved

from http//patrickiroegbu.yahoo.com/2009/okija.

Mbiti, J.S. (1975). Introduction to African Religion. London: Heinemann.

(1970). Concept of God in Africa. London: Heinemann.

Metuh, E. 1. (1981). God and man in African religion. London: Chapman.

Njoku, F. O. C. (2002). Essays in African philosophy, thoughts and theology. Owerri: Claretain.

Njoku, M. (2018). Personal Communications.

Nwamara, M. (2018). Personal Communications.

Onyeike, G (2018) Personal Communication.

Onuzor, E. (2018). Personal Communication.

Obiechina, E. (1984). Culture, tradition and society in the West African novel. Cambridge: Cambridge university.

Onwu, D. N. E. (2002). Uzo ndu na eziokwu: Towards the understanding of igbo traditional religious life and philosophy. Retrieved from http://ahiajioku.igbonet.com/2002/igbo. 